\section{Report on Verification of}

\section{Mogfeen 240EC efficacy on}

\section{Garlic (Allium sativum $L$ ) weeds at Bale zone, South Eastern}

\section{Ethiopia}

\section{Guta Eshetu* and Mohammedamin Abdulrezak}

Oromia Agricultural Research Institute, Sinana Agricultural Research center, P.O.Box 208, Ethiopia
Received: 01 September, 2020

Accepted: 19 October, 2020

Published: 20 October, 2020

*Corresponding author: Guta Eshetu, Oromia Agricultural Research Institute, Sinana Agricultural Research center, P.O.Box. 208, Ethiopia,

E-mail: eshetuguta@gmail.com

Keywords: Relative weeds density; Weed index; Weed control index; Broad leave weeds; Grass weeds

https://www.peertechz.com

\section{Check for updates}

\begin{abstract}
Garlic Herbicide verification trial was conducted at Goba and Sinana districts of Bale highlands south eastern Ethiopia. CBD was used for this experiment. Mogfeen 240EC herbicide was verified by SARC at on station and Goba in 2018 Gena season. The effects of herbicide on the growth, yield components and Yield of Garlic had determined. On the other hand, parameters such as relative weed density (RWD), Weed Index (WI) and Weed Control Index (WCI) were collected to determine the efficacy of Mogfeen 240EC on broadleaf weeds, Sedges and Grass weeds. Accordingly, $99 \%$ of Broad leaf weeds and $1 \%$ grass weeds were observed before herbicide application. Mogfeen 240EC reduces broad leaves weed by about $82.73 \%$ and grass weeds by about $63.022 \%$ within first round application. On the other hand, the efficiency of this herbicide in controlling broad leaves weeds within the first round application round was about $73.17 \%$ whereas its efficiency in controlling grass weeds was $93.22 \%$. Within the second round application 15 days later of first round application all weeds were controlled completely. On the other hand, plots treated with the herbicide showed about $68.42 \%, 7.02 \%$ yield advantage over weed free and hand weeded plots respectively. Therefore, Mogfeen 240 EC herbicide was verified and recommended for the production of Garlic at Bale and similar agro ecologies.
\end{abstract}

\section{Introduction}

Garlic (Allium sativum L) is one of the important bulb crop grown in the world as well as in Ethiopia for a long period of time. Botanically it is known as Allium sativum and is a member of Aliacea family. It is native to central Asia. Garlic contains active ingredients known as Allicin which gives its pungent flavor along with ample of health benefits [1].

Garlic production spread throughout the country and has been cultivated under irrigated as well as rain fed conditions, mainly in the mid and highlands of Ethiopia [2]. According to Ethiopia central statistical agency report of 2016/2017; 15,381 ha of land was covered by Garlic and 1,386,643.07 Quintals of Garlic were produced annually. On the other hand, this report also indicated that about 90.15 Quintals of Garlic can be harvested from one hectare of land (CSA, 2016/17).

Despite the higher importance of the crop its production and productivity is very low due to different problems. There are many Biotic and A biotic factors contributing for lower production of Garlic among which in appropriate agronomic practice especially weeding is the major problem.

Weed infestation in garlic is one of the major factors for loss in yield and bulb loss to the tune of $30-60 \%$ [3]. Weed reduces the bulb yield to the extent of 40 to $80 \%$ [4,5]. In garlic shallow root system make mechanical method of weed control difficult and sometimes causes damage to developing bulbs [3]. The predominant weed flora that hampers the growth and yield of crop vary with soil type, moisture, and other climatic factors.

Garlic is closely planted and shallow rooted bulbous crop. Therefore, intercultural practices are very difficult to undertake and manual weeding during the establishment stage of crop causes physical damage to crop plant. A most of troublesome problem faced by garlic grower is the control of weeds during early stage of crop growth. Because of higher plant density and slow growth of plant, inter-culturing is practically difficult 
and crop suffers heavily from weed competition during establishment of plant. The weeds compete for moisture, space, nutrients and light which affect growth and development of crop. Therefore, it is essential to keep field weed free during critical period of crop growth.

However, manual hand weeding is a very tedious and intensive labor requiring method of weed control. Sometimes due to shortage of labor and unexpected rains, hand weeding or mechanical weed operations are delayed or left altogether. The chemical weed control in garlic has received little attention and weeds are mostly managed manually. In such situation, herbicides offer the most practical, more effective and economical method of weed control for increasing bulb yield of garlic. But there is no herbicide for weed control of Garlic in Ethiopia. Hence, present investigation was conducted to verify the efficacy of imported herbicide controlling weed growth and enhancing the bulb yield of garlic.

The Objective of the study was to verify the efficacy of Mogfeen240EC on different weeds of Garlic (Allium Sativum L)

\section{Materials and methods}

The Experiment was conducted at Sinana On station and Goba to determine the efficacy of herbicide brought from abroad. Sinana is located at about $460 \mathrm{Km}$ ton southeast of Addis Ababa and it has an altitude of $2400 \mathrm{~m}$ above sea level. Its geographical location ranges from $07^{\circ} 06^{\prime} 12^{\prime \prime}$ to $07^{\circ} 07^{\prime} 29^{\prime \prime}$ northern latitude and from $40^{\circ} 12^{\prime} 40^{\prime \prime}$ to $40^{\circ} 13^{\prime} 52^{\prime \prime}$ eastern longitude. On the other hand, Goba is located in Bale zone of Oromia regional state of approximately $446 \mathrm{~km}$ south east of Addis Ababa. The district has latitude, Longitude, an elevation of $7^{\circ} 0^{\prime} \mathrm{N}, 39^{\circ} 59^{\prime} \mathrm{E}, 2743 \mathrm{~m}$.a.s.l respectively.

Sprout seed of Garlic local variety was bought from local market and planted using $10 \mathrm{~cm} \times 30 \mathrm{~cm}$ spacing between plants and rows at Goba and Sinana Research station. Both NPS and UREA fertilizer was applied according to recommendation. All agronomic practices except weeding control were followed similarly for all plots of the experiment. Three weeks later of planting; one week after emergency Mogfeen240EC was sprayed to one plot according to recommendation (1litre/ha) using hand operated Knapsack sprayer and the remaining one plot remained for control (It is weed free plot). There is no standard check because this herbicide is the first to introduce for Garlic weed control. There was one hand weeded plot for comparison. Therefore, the experiments had three plots at each location. Mogfeen240EC sprayed twice within fifteen days' interval at both locations throughout the crop life cycle.

On the other hand, to determine the efficacy of the herbicide weeds were counted by throwing the $50 \mathrm{~cm} \times 50 \mathrm{~cm}$ quadrate three times on each plots before spraying. The average number of weeds counted from three quadrates was converted to mean number of weeds per $\mathrm{m}^{2}$. The weeds were categorized as broad leaves weeds, Sedges and Grass weeds based on their leaf morphological characteristics. This was the way of determining weed density of the crop and efficiency of herbicides to control weeds. Accordingly; Number of Broad leaves weeds per $\mathrm{m}^{2}$,
Number of grass weeds per $\mathrm{m}^{2}$, Relative weed density, Weed Index and weed control Index was determined.

\section{Relative weed density}

Defined as the ratio of particular weed species to total weed population expressed in percentage. Therefore, it was calculated by dividing the number of particular weed species by total weed species in experimental plot.

$$
\text { RWD }=\frac{\text { Number of particular weed }}{\text { Total Number of weeds }} \times 100
$$

\section{Weed index}

Is the average yield difference of hand weeded plot and treated plot divided by average yield of hand weeded plot of the experiment and calculated as the following.

$$
\mathrm{WI}=\frac{(\text { Yield of hand Weeded Plot }- \text { Yield of Treated Plot })}{\text { Yield of Hand weeded plot }} \times 100
$$

\section{Weed control index}

Is weed controlling efficiency of herbicide and calculated using the following formulae. Sometimes it was also named as weed susceptibility index

$$
\mathrm{WCI}=\frac{(\text { Weed count in weedy checkplot }- \text { weed count in treated plot })}{\text { Weed count in weedy check plot }} \times 100
$$

\section{Statistical data analysis}

All data were collected and analyzed using GenStat $15^{\text {th }}$ Edition computer software. The significant difference among treatments was determined using Duncan Multiple range test (DMRT) at $5 \%$ level of significance.

\section{Result and discussion}

To determine the efficacy of herbicide weed density was determined by categorizing them into broad leaf weeds and grass weeds since they were the main investigated types of weeds. Different Weed species were investigated at SARC on station and whereas only Avena fatua was observed at Goba Experimental site.

The detailed description of the observed weeds at both experimental sites is depicted in the following table 1.

Number of Broad leaves and Grass weeds per $\mathrm{m}^{2}$ were determined at the time of mogfeen $240 \mathrm{EC}$ application for each plot. Accordingly; average number of broad leaves weeds (759.43) and grass weeds (30) were observed per $\mathrm{m}^{2}$ at Sinana Experimental site. The relative weed density of grass and Broad leaf weeds was also calculated. Accordingly, 99\% of Broad leaf weeds and $1 \%$ grass weeds were observed before herbicide application. In weed free plot during application $92.12 \%$ of broad leaves weeds and $7.88 \%$ of grass weeds were investigated. However, at Goba experimental site Only Avena Fatua was investigated. On the other hand, at the same time with herbicide application hand weeding was also done for adjacent plot for comparison. Application of herbicide was continued within fifteen days' interval in similar ways with 
hand weeding. The following pictures showed the efficiency of mogfeen $240 \mathrm{EC}$ in controlling both grass and Broad leaf weeds at SARC on station Figures 1,2.

Five days later of Mogfeen240EC application, numbers of weeds were counted using the same procedure. The following data were recorded after first round spray before the second round herbicide application.

As it is indicated in the above table number of both broad leaves weed and grass weeds were reduced after application of Mogfeen240EC and this contribution enhances the crop growth parameters, Yield components and Yield of Garlic. Mogfeen240EC reduces broad leaves weed by about $82.73 \%$ and grass weeds by about $63.022 \%$ within first round application. On the other hand, the efficiency of this herbicide in controlling broad leaves weeds within the first round application round was about $73.17 \%$ whereas its efficiency in controlling grass weeds was $93.22 \%$. This indicates the efficacy of the herbicides the requirements of second round herbicide application Table 2.

Fifteen days' later Mogfeen240EC was applied since weeds were not completely controlled and there was suitable rainfall condition which favors the growth and development of weeds. Before second round application number of weeds per Quadrate were counted; converted to average number of weed per $\mathrm{m}^{2}$ and the following average number of broad leaves weeds and grass weeds were recorded. Within second round application

Table 1: Description of weeds observed Sinana and Goba Experimental site.

\begin{tabular}{|c|c|c|c|}
\hline S.N & Species name of the weeds & Family name & Common name \\
\hline 1 & Amaranthus Cruentus & Amaranthuceae & Amaranthus \\
\hline 2 & Datura Stramonium & Solonaceae & Datura \\
\hline 3 & Avena fatua & Poaceae & Avena \\
\hline 4 & Rumex acetosa & Polygonaceae & Rumex \\
\hline 5 & Rumex nepalensis & Polygonaceae & Rumex \\
\hline 6 & Bidens ghedoensis & Asteraceae & Bidens \\
\hline 7 & Chenopodium Album & Chenopodiaceae & Chenopodium \\
\hline 8 & Cyperus aterrimus & Cyperaceae & Cyperus \\
\hline
\end{tabular}

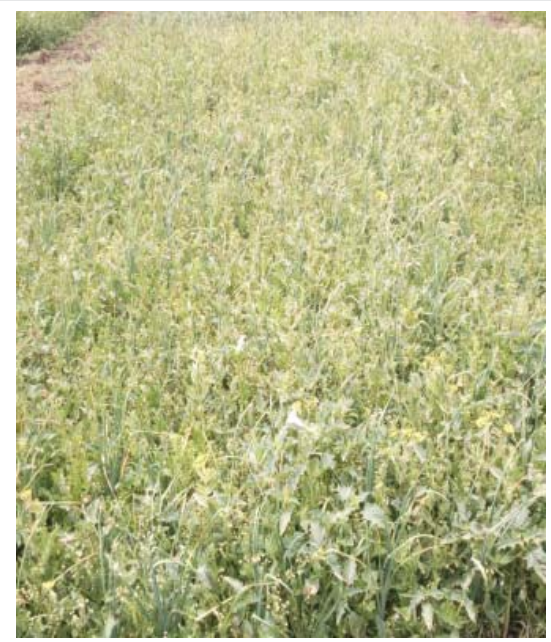

Figure 1: Garlic plot before Mogfeen240EC application.

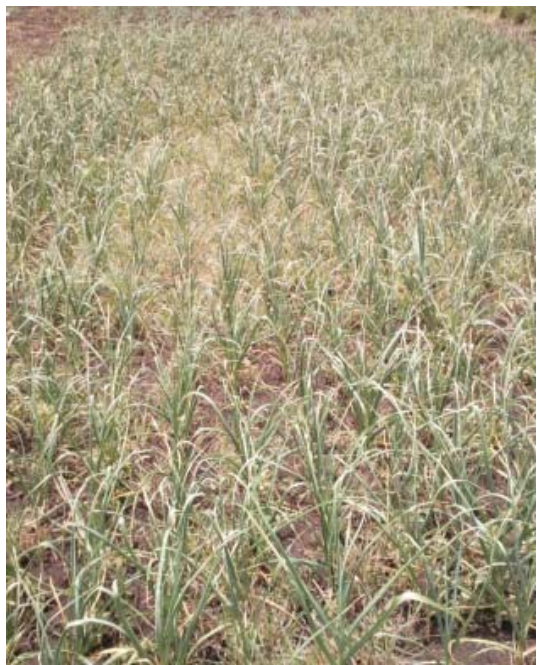

Figure 2: Garlic plot after Mogfeen 240EC application.

Table 2: Weed density before and after application of Mogfeen240EC

\begin{tabular}{|c|c|c|c|c|}
\hline Treatments & $\begin{array}{c}\text { NOBLW/m }{ }^{2} \text { Before } \\
\text { Appn }\end{array}$ & $\begin{array}{c}\text { NOGW/ } \mathbf{m}^{2} \text { Before } \\
\text { Appn }\end{array}$ & $\begin{array}{c}\text { NOBLW/ } \\
m^{2} \\
\text { After } \\
\text { Appn }\end{array}$ & $\begin{array}{c}\text { NOGW/ } \mathbf{m}^{2} \text { After } \\
\text { Appn }\end{array}$ \\
\hline $\begin{array}{c}\text { Mogfeen240EC } \\
\text { sprayed }\end{array}$ & 926.67 & 9.33 & 160 & 3.45 \\
\hline Weed free & 592 & 50.67 & 596.33 & 50.86 \\
\hline Hand weeded & 0 & 0 & 0 & 0 \\
\hline
\end{tabular}

of herbicide Both Broad leaves and grass weeds were fully controlled as it is indicated in the following table. The Broad leaves weed control Index of Mogfeen240EC during the second application round is $99.85 \%$ whereas, the grass weeds control Index of the herbicide at the same application round is about $100 \%$. This indicates the efficiency of this herbicide to control both broad leaves and grass weeds within second round spraying.

The weed control Index of herbicide of the second round application is greater than that of the first round application. This may due to the lower density of weeds during second round application and the weakness of weeds to stand against herbicide Table 3.

The reduction in number of weeds in turn have great role in increasing the yield by enhancing the growth and development of yield components of Garlic. In fact, if weeds are controlled; the competition of crop for sun light, soil moisture, and carbon dioxide will be decreased and the growth and development of yield components of the crop will be enhanced which in turn increases the yield of the crop. In similar manner with other weed controlling agents Mogfeen240EC fully controlled the weeds and favor the yield components of Garlic. The result showed that herbicide application significantly affects plant height, weight of single bulb, Number of cloves per bulb and bulb yield. The following data were recorded Table 4 .

\section{Conclusion and recommendation}

Mogfeen240EC was applied to Garlic to control all weeds 
Table 3: Weed density during and after second round Mogfeen240EC application.

\begin{tabular}{|c|c|c|c|c|}
\hline Treatments & $\begin{array}{c}\text { NOBLW/m } \mathbf{m}^{2} \text { Before } \\
\text { Appn }\end{array}$ & $\begin{array}{c}\text { NOGW/m2 } \\
\text { Before Appn }\end{array}$ & $\begin{array}{c}\text { NOBLW/m } \mathbf{m}^{2} \\
\text { After Appn }\end{array}$ & $\begin{array}{c}\text { NOGW/m } \\
\text { After Appn }\end{array}$ \\
\hline $\begin{array}{c}\text { Mogfeen240EC } \\
\text { sprayed }\end{array}$ & 160 & 114.67 & 1.01 & 0 \\
\hline Weed free & 652.73 & 177.93 & 655.37 & 178.84 \\
\hline Hand weeded & 0 & 0 & 0 & 0 \\
\hline
\end{tabular}

Table 4: Effects of Mogfeen240EC application on the growth, yield and yield related parameters of Garlic.

\begin{tabular}{|c|c|c|c|c|c|}
\hline PN & Treatments & PH & WSB & NCPB & YLD (Qt ha-1) \\
\hline 1 & Mogfeen240EC spraying & 23.8 & 22.4 & 8.8 & 57 \\
\hline 2 & Hand Weeding & 23.6 & 15.3 & 12.4 & 53 \\
\hline 3 & Weed free & 24.2 & 12.3 & 8 & 18 \\
\hline 4 & Mean & 23.87 & 16.67 & 9.73 & 36.66 \\
\hline
\end{tabular}

PN: Plot Number; PH: Plant Height; WSB: Weight of Single Bulb; NCPB: Number of Cloves Per Bulb; YLD: Yield

grown in the crop. There were different types of weeds observed in the experimental site at both Goba and Sinana on Station Research site. Based on the morphological characteristics of the leaves the investigated weed types can be categorized as Broad leaves, grass and sedges. All types of weeds were controlled by applying Mogfeen $240 E C$ twice the crop growing cycle. On the other hand, using this herbicide gives comparable yield with that of hand weeded plot. Therefore, it is recommended to be used by Garlic producing community for effective and economical weed management.

\section{References}

1. Sethi N, Kaura S, Dilbaghi N, Parle M (2014) Garlic: A pungent wonder from nature. International Journal of Pharmacy 5: 523-529. Link: https://bit.ly/3IXTf02

2. Lawande KE, Khar A, Mahajan V, Srinivas PS, Sankar V, et al. (2009) Onion and Garlic research in India. J Hort Sci 4: 91-119. Link: https://bit.ly/2FGNc0v

3. Verma SK, Singh T (1996) Weed control in kharif onion (Allium cepa L.). Ind J Weed Sci 28: 48-51. Link: https://bit.ly/3jbFl8H

4. Osman AH, Osman MY (2017) Opportunity and Challenges of Garlic production in Allaybaday Area' Gollis University A thesis submitted in partial fulfillment of the requirement of Bachelor of Agriculture and Natural Resource Management $1-6$.

5. Ayalew A, Tadesse D, Medhin ZG, Fantaw S (2015) Evaluation of Garlic (Allium sativum L.) Varieties for Bulb Yield and Growth at Dabat, Northwestern Ethiopia. Open Access Library Journal 2: e1216. Link: https://bit.ly/2FEcOee
Discover a bigger Impact and Visibility of your article publication with

Peertechz Publications
Highlights

* Signatory publisher of ORCID

* Signatory Publisher of DORA (San Francisco Declaration on Research Assessment)

* Articles archived in worlds' renowned service providers such as Portico, CNKI, AGRIS, TDNet, Base (Bielefeld University Library), CrossRef, Scilit, J-Gate etc.

* Journals indexed in ICMJE, SHERPA/ROMEO, Google Scholar etc.

* OAI-PMH (Open Archives Initiative Protocol for Metadata Harvesting)

* Dedicated Editorial Board for every journal

* Accurate and rapid peer-review process

* Increased citations of published articles through promotions

- Reduced timeline for article publication

Submit your articles and experience a new surge in publication services (https://www.peertechz.com/submission).

Copyright: (c) 2020 Eshetu G, et al. This is an open-access article distributed under the terms of the Creative Commons Attribution License, which permits unrestricted use, distribution, and reproduction in any medium, provided the original author and source are credited. 